\title{
A national survey of managed honey bee 2015-2016 annual colony losses in the USA
}

\author{
Kelly Kulhanek, Nathalie Steinhauer, Karen Rennich, Dewey M Caron, \\ Ramesh R Sagili, Jeff S Pettis, James D Ellis, Michael E Wilson, James T \\ Wilkes, David R Tarpy, Robyn Rose, Kathleen Lee, Juliana Rangel \& Dennis \\ vanEngelsdorp
}

To cite this article: Kelly Kulhanek, Nathalie Steinhauer, Karen Rennich, Dewey M Caron, Ramesh R Sagili, Jeff S Pettis, James D Ellis, Michael E Wilson, James T Wilkes, David R Tarpy, Robyn Rose, Kathleen Lee, Juliana Rangel \& Dennis vanEngelsdorp (2017) A national survey of managed honey bee 2015-2016 annual colony losses in the USA, Journal of Apicultural Research, 56:4, 328-340, DOI: 10.1080/00218839.2017.1344496

To link to this article: https://doi.org/10.1080/00218839.2017.1344496
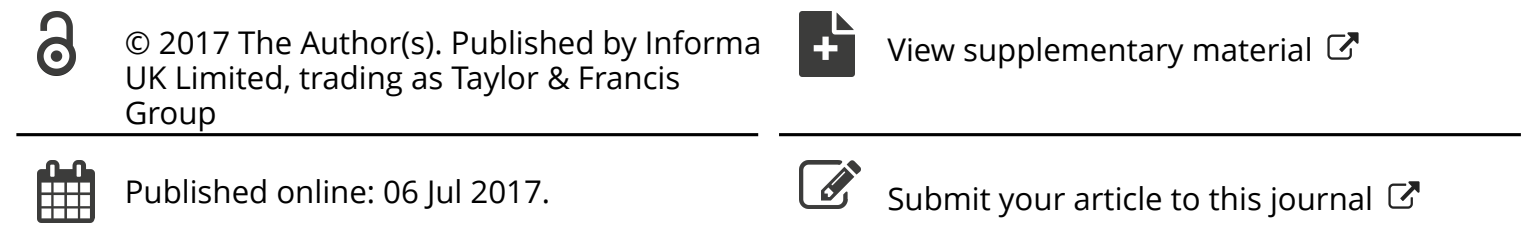

Џll Article views: 1203

View related articles $\square$

View Crossmark data ¿

(1)




\title{
ORIGINAL RESEARCH ARTICLE
}

\section{A national survey of managed honey bee 2015-2016 annual colony losses in the USA}

Kelly Kulhanek ${ }^{a}$ (D) Nathalie Steinhauer ${ }^{a}$ D , Karen Rennich ${ }^{a}$, Dewey M Caron ${ }^{b}$, Ramesh R Sagili ${ }^{b}$, Jeff S Pettis ${ }^{c}$ (D), James D Ellis ${ }^{d}$, Michael E Wilson ${ }^{e}$, James T Wilkes ${ }^{f}$ D, David R Tarpy ${ }^{g}$, Robyn Rose ${ }^{h}$ D, Kathleen Lee ${ }^{i}$, Juliana Rangel ${ }^{j}(D)$ and Dennis vanEngelsdorp ${ }^{a^{*}}$

${ }^{a}$ Department of Entomology, University of Maryland, College Park, MD, USA; ${ }^{b}$ Department of Horticulture, Oregon State University, Corvallis, OR, USA; 'Institute of Bee Health, University of Bern, Bern, Switzerland; ' $D$ Department of Entomology and Nematology, University of Florida, Gainesville, FL, USA; ${ }^{\mathrm{e}}$ Department of Entomology and Plant Pathology, University of Tennessee, Knoxville, TN, USA; ' Department of Computer Science, Appalachian State University, Boone, NC, USA; ${ }^{g}$ Department of Entomology and Plant Pathology, North Carolina State, University,

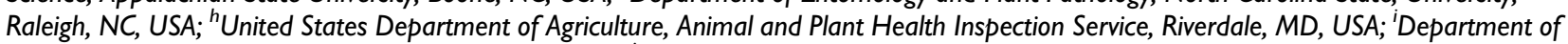
Entomology, University of Minnesota, St. Paul, MN, USA; 'ंDepartment of Entomology, Texas A\&M University, College Station, TX, USA

(Received 5 January 2017; accepted 13 June 2017)

\begin{abstract}
Managed honey bee colony losses are of concern in the USA and globally. This survey, which documents the rate of colony loss in the USA during the 2015-2016 season, is the tenth report of winter losses, and the fifth of summer and annual losses. Our results summarize the responses of 5725 valid survey respondents, who collectively managed 427,652 colonies on I October 2015 , an estimated $16.1 \%$ of all managed colonies in the USA. Responding beekeepers reported a total annual colony loss of $40.5 \%$ [95\% Cl 39.8-4I.I\%] between I April 2015 and I April 20I6. Total winter colony loss was $26.9 \%$ [ $95 \% \mathrm{Cl} 26.4-27.4 \%]$ while total summer colony loss was $23.6 \%$ [95\% Cl $23.0-24.1 \%]$, making this the third consecutive year when summer losses have approximated to winter losses. Across all operation types, $32.3 \%$ of responding beekeepers reported no winter losses. Whilst the loss rate in the winter of 2015-2016 was amongst the lowest winter losses recorded over the ten years this survey has been conducted, $59.0 \%(n=3378)$ of responding beekeepers had higher losses than they deemed acceptable.
\end{abstract}

\section{Encuesta nacional 20I5-20I6 sobre pérdidas anuales de colonias de la abeja de la miel manejada en los EE.UU}

\begin{abstract}
Las pérdidas de colonias de abejas manejadas son preocupantes en los Estados Unidos y en el mundo. Esta encuesta, que documenta la tasa de pérdida de colonias en los EE.UU. durante la temporada 2015-2016, es el décimo informe de las pérdidas de invierno, y el quinto de las pérdidas de verano y anuales. Nuestros resultados resumen las respuestas de 5.725 encuestados válidos, quienes colectivamente manejaron 427.652 colonias el I de octubre de 20I5, un $16.1 \%$ de todas las colonias manejadas en los Estados Unidos. Los apicultores respondieron con una pérdida total de colonias anual del $40.5 \%$ [IC del 95\%: 39.8-4I.I\%] entre el I de abril de 2015 y el I de abril de 2016. La pérdida total de colonias de invierno fue del $26.9 \%$ [IC del $95 \%$ : 26.4-27.4\%], y las de verano del $23.6 \%$ [IC del $95 \%: 23.0-24.1 \%$ ], lo que lo convierte en el tercer año consecutivo en que las pérdidas del verano se han aproximado a las pérdidas de invierno. En todos los tipos de operaciones, el $32.3 \%$ de los apicultores que respondieron no reportaron pérdidas de invierno. Mientras que la tasa de pérdidas en el invierno de 2015-2016 fue una de las pérdidas de invierno más bajas registradas durante los diez años que se han realizado esta encuesta, el $59.0 \%(n=3.378)$ de los apicultores que respondieron tuvieron mayores pérdidas de las que consideraban aceptables.
\end{abstract}

Keywords: Apis mellifera; honey bee; overwinter; mortality; colony losses; 2015-2016

\section{Introduction}

Managed honey bees (Apis mellifera) add $\$ 15$ billion worth of pollination services to US agriculture annually (Morse \& Calderone, 2000). Insect pollinators provide over 153 billion euros (€I53 billion) in crop production worldwide (Gallai, Salles, Settele, \& Vaissière, 2009), including estimates of values ranging from $\$ 0.38$ billion in the UK (Carreck \& Williams, 1998) to $\$ 6.4$ billion in the EU (Borneck \& Merle, 1989). Ongoing high rates of colony mortality threaten the supply of sufficient colonies needed to pollinate fruit, nut and other specialty crops (Calderone, 2012). For instance, US honey bee populations declined by $61 \%$ between 1947 and 2008 (Ellis, Evans, \& Pettis, 2010; vanEngelsdorp \& Meixner, 2010). Despite high levels of severe colony losses over the last 10 years, the total number of colonies managed in the US has, however, increased from 2.39 million in 2006, when colony collapse disorder (CCD) was first reported (Cox-Foster et al., 2007), to 2.59 million in 2016 (USDA-NASS, 2016). This increase can be explained by the ability of beekeepers to replace dead

\footnotetext{
*Corresponding author. Email: dvane@umd.edu
} 
colonies through splitting existing colonies into two or more units (vanEngelsdorp \& Meixner, 2010). Since splitting colonies involves labor and financial costs, particularly for large commercial operations who perform hundreds or thousands of splits in a year, the long-term sustainability of operations that suffer these high loss rates is threatened.

Colony mortality can result from a multitude of interacting factors including forage availability (Decourtye, Mader, \& Desneux, 20l0), pesticide exposure (Zhu, Schmehl, Mullin, \& Frazier, 20I4), issues associated with the ectoparasitic mite Varroa destructor (Neumann \& Carreck, 2010), other pests, parasites and diseases (Berthoud, Imdorf, Haueter, Radloff, \& Neumann, 20I0), as well as various other socioeconomic factors (Gallai et al., 2009). With the initial concern raised by CCD, beekeepers and scientists began monitoring colony loss rates annually (Lee et al., 2015; Seitz et al., 2016, Spleen et al., 2013; Steinhauer et al., 20l4; vanEngelsdorp et al., 2012; vanEngelsdorp, Hayes, Underwood, \& Pettis, 2008, 2010, 20II; vanEngelsdorp, Underwood, Caron, \& Hayes, 2007), giving context to annual mortality rates, which then allows for identifying potential causes of and solutions to poor bee health.

The Bee Informed Partnership (BIP, beeinformed.org) has conducted winter colony loss surveys in the USA since 2006-2007. The present survey, like previous BIP surveys, calculates colony loss rates indirectly, by quantifying the number of colonies alive on a specific date and obtained over specific time periods (vanEngelsdorp et al., 2010, 20I3). Total winter loss has ranged from a low of $22 \%(201 \mathrm{I}-2012,2014-2015)$ to a high of $36 \%$ (2007-2008). Total summer loss has ranged from 24 to $25 \%(2012-2014)$. Finally, annual loss has ranged from $34 \%(2013-2014)$ to $45 \%$ (20I2-20I3) (Lee et al., 2015; Seitz et al., 2016; Spleen et al., 2013; Steinhauer et al., 2014; vanEngelsdorp et al., 2007, 2008, 20I0, 20II, 2012). Beekeeper-defined acceptable annual losses in previous US surveys have ranged from 13.2 to 19.1\% (Lee et al., 2015; Seitz et al., 2016; Spleen et al., 2013; Steinhauer et al., 2014; vanEngelsdorp et al., 2007, 2008, 2010, 2011, 2012).

Surveys conducted by BIP do not solicit responses randomly, and thus are potentially biased, as the demographics of its respondents may not be reflective of the industry as a whole. To conduct a random survey, a national public registry of all beekeepers is needed from which to select respondents. The National Agricultural Statistics Service (NASS) maintains a list of all known farming operations in the US, including beekeepers. NASS does lend technical assistance and conducts surveys for private organizations and other government agencies. This can, however, be prohibitively expensive depending on the amount of work NASS is required to perform. To address concerns over potential biases of the BIP survey, the "National strategy to promote the health of honey bees and other pollinators" released by the White House (Vilsack \& McCarthy, 2015) tasked
NASS to produce annual, US and state level estimates on the number of honey bee colonies, colonies lost, and colony health. NASS had already been surveying beekeepers for its Honey report, using a stratified random sample of all known beekeeping operations with five or more colonies that also qualified as a farm. A panel was chosen from this sample and tracked on a quarterly basis throughout the year to produce the Honey Bee Colonies report. While BIP personnel were consulted during the development of the NASS survey, not all questions were identical and so direct comparisons of results must be made with caution. Nevertheless, the questions and results pertaining to these two surveys are sufficiently similar to permit some comparisons. NASS recently published results (USDA-NASS, 2016) allowing a one year comparison of results between these two different efforts.

As with previous BIP loss reports, here we document summer, winter, and annual colony losses that were selfreported by beekeepers across the USA from I April 2015 to I April 2016. This is the fifth survey to include the summer and annual time periods and the tenth survey reporting winter losses. We classified beekeepers by operation type based on the number of colonies they managed as "backyard" ( $\leq 50$ colonies), "sideline" (5I500 colonies), or "commercial" (>500 colonies), and compared colony loss rates between these three groups. Furthermore, as done previously, we compared colony loss rates among beekeepers in different groupings, including those grouped by state, migratory practice, participation in California almond pollination, self-reported causes of loss, and self-declared acceptable annual loss rate. Annual data on the estimated percent of colonies lost in the USA enabled us to compare the current survey results to those of prior years. Such comparisons help monitor the status of colony losses and honey bee health at the population level.

\section{Materials and methods}

\section{Survey}

Beekeepers were invited to participate in our annual colony loss survey via email through distribution lists maintained by two national beekeeping organizations (American Beekeeping Federation and American Honey Producer's Association), a beekeeping supply company (Brushy Mountain Bee Farm), two honey bee brokers, two beekeeping journals (American Bee Journal and Bee Culture), two subscription listservs (Catch the Buzz and ABFAlert), and the BIP mailing list $(n=15,328)$. The email directed participants to an online survey hosted via www.SelectSurvey.net. As a survey of convenience with a snowballing recruitment, emails asking beekeepers to participate in the survey also requested that respondents forward the survey invitation to fellow beekeepers who may also want to participate. Requests to distribute the survey were also sent to the Apiary Inspectors of America, state extension apiculturists, 
industry leaders including the American Beekeeping Federation $(A B F)$ and the American Honey Producers Association (AHPA), and to a number of regional beekeeping clubs, including the Eastern Apicultural Society (eastern USA), the Heartland Apicultural Society (central USA), and the Western Apicultural Society (western USA). To ensure we received adequate representation from commercial beekeepers, we also mailed paper surveys to commercial beekeepers identified by state apiary inspectors $(n=1100)$. The survey was available online from I April 2016 to 30 April 2016. Paper surveys were mailed by the end of March and were accepted through to 29 July 2016.

The "loss survey" asked quantitative questions about the number of colonies in an operation and objective questions about perceived causes of loss and acceptable annual loss rates. This was followed by an optional "management survey." The present study addresses only responses to the loss survey, which has included the same core questions for summer, winter, and annual losses since 2013-2014 (Lee et al., 2015; Seitz et al., 2016; Spleen et al., 2013; Steinhauer et al., 20l4; vanEngelsdorp et al., 2013). Loss seasonal periods are defined as I April 2015 to I October 2015 (summer), I October 2015 to I April 2016 (winter), and I April 2015 to I April 2016 (annual) (Lee et al., 2015; Seitz et al., 2016; Spleen et al., 2013; Steinhauer et al., 20l4; vanEngelsdorp et al., 2007, 2008, 20I0, 20II, 20I2).

Duplicate responses and responses from non-US beekeeping operations were filtered out from the database. Responses with insufficient or illogical answers were also excluded. The "cause of loss" question included an open "Other: please specify" response. Specified "Other" causes of loss were either kept separate if they were truly unique, or were re-categorized into the appropriate cause of loss response. For example, a respondent who chose "Other" and specified "Flood" was re-categorized into the "Natural Disaster" cause of loss category.

Once the invalid responses were filtered out of the database, we created three subsets for analysis of valid summer, winter, and annual colony losses. Creation of these subsets was necessary because not all respondents answered all questions. We only included a respondent's results in a given period if they had at least one colony at the start of a given period. Respondents were also categorized into three "operation type" groups, determined by the number of colonies they managed on I October 20I5. "Backyard beekeepers" managed 50 or fewer colonies, "sideline beekeepers" between $5 \mathrm{I}$ and 500 colonies, and "commercial beekeepers" more than 500 colonies.

\section{Statistics}

Total and average colony losses for summer, winter, and the annual period were calculated for all operations based on vanEngelsdorp et al. (20I3) and R code first used in Steinhauer et al. (20/4). We first calculated per- centage of operational losses for each respondent by dividing the number of colonies lost by the number of colonies at risk during each time period (summer, winter, annual). Total loss rate was then calculated by dividing the total number of colonies lost by the number of colonies at risk in that time period, and then multiplying the resulting number by 100 . Total loss calculations count each individual colony without factoring in operation size, meaning that responses from beekeepers with larger operations exert a greater weight in total loss calculations than beekeepers with smaller operations. Total loss percentages are more representative of commercial beekeepers because they manage significantly more colonies ( $n=378,693)$ than the smaller operations (sideline and backyard) combined ( $n=48,959)$.

For comparison, we also calculated average loss, where the total loss of each operation is calculated and all operational total losses are summed and divided by the number of responding operations. Average loss facilitates better comparison between subsets of beekeepers. Average loss was calculated by adding each operational loss for a given period, then dividing that sum by the number of valid respondents in that time period.

Ninety-five percent confidence intervals $(95 \% \mathrm{Cl})$ for total losses were calculated using a generalized linear model with a quasi-binomial distribution (R Development Core Team, 2016). Average loss 95\% confidence intervals $(\mathrm{Cls})$ were calculated using the Wald formula (vanEngelsdorp et al., 20l3).

Differences in loss rates between operational sizes were identified with the Kruskal-Wallis rank sum test. We looked for differences in loss rates between operation size, migratory vs. stationary beekeepers, participation vs. non-participation in almond pollination, acceptable vs. higher than acceptable loss, and between various self reported causes of death. When multiple comparisons were conducted, the Kruskal-Wallis test was followed by the Mann-Whitney $U$ test (also known as Wilcoxon Rank Sum test) for a pairwise check of significance using a Bonferroni correction. Chi squared tests were used to check for differences between operation types, and for other groupings. All statistical tests were performed using the statistical program $R$ ( $R$ version 3.3.I (2I June 20I6)) and all tests used a significance level of $\alpha=0.05$.

We followed the USDA-NASS method to report state colony losses by counting colonies of multistate beekeepers in each state which the beekeeper reported having colonies (USDA-NASS, 2016). If a state had five or fewer respondents, the losses for that state were not reported to maintain the anonymity of the respondent(s).

\section{Self-reported causes of loss}

To understand the potential impact on colony loss rates by different reported causes of loss, we analyzed what percentage of total winter losses were attributable to 
each reported cause of loss. We considered the top three reported risk factors, meaning those self-reported factors that directly cause colony loss. These factors were - "Varroa" (Genersch et al., 2010; Giacobino et al., 20I5), "Queen failure" (Brodschneider et al., 2016; vanEngelsdorp et al., 20I3) and "Pesticides" (Traynor et al., 2016). We then estimated how many colonies were lost to these risk factors by counting how many colonies were lost by each beekeeper who reported each cause. For example, if a beekeeper who lost 50 colonies reported only "Queen Failure," we attributed 50 colonies of the total winter colony losses ( $n=145,106)$ to "Queen Failure." If a beekeeper reported more than one of the top three risk factors (i.e., reported "Queen failure" and "Varroa"), we divided his loss equally among the categories "Queen failure + Other" and "Varroa + Other." A beekeeper who lost 50 colonies would have 25 lost colonies attributed to each of the two categories. The " + Other" categories also include beekeepers who selected a top three risk factor and one or more causes of loss other than the top three risk factors (i.e., a beekeeper who lost 50 colonies and reported "Queen failure," and "Starvation" would give 50 lost colonies to "Queen Failure + Other"). The "All Other" category contains beekeepers who had a winter loss and reported one or more causes of loss other than the top three risk factors. We did this for each beekeeper who reported a cause of loss.

\section{Comparison to USDA-NASS survey}

In 2015-2016, NASS collected and reported loss data for the first time. There are a few notable differences in the numbers reported and the methodology used to calculate losses between NASS and BIP loss reports. First, NASS divides the year into quarterly time periods as opposed to our half year breakdown (summer and winter). For each quarter, NASS reports the number of colonies at the start of the period, the number of colony additions, and the number of colonies lost for each quarter. A state level "maximum" number of colonies is also calculated by adding all colonies that were in the state on the Ist of the quarter, plus all those which moved in during the quarter.

NASS calculates loss by directly asking each respondent how many colonies died over a given time period in each state an operation was in during the quarter. $A$ state level loss ratio is calculated by dividing the number of colonies lost in a state during the quarter by the number of colonies with the potential to be lost in a state during that quarter (defined by NASS as the "Maximum colonies".) At the US level, no Maximum colonies exists due to duplication, so the national loss ratio is total number of colonies lost divided by the total number of colonies on the first of the quarter. BIP calculates loss indirectly by calculating change in colony numbers over time to include fluctuations caused by splitting. We could not use BIP calculation methods to compare losses by quarter because we did not have colony counts for each quarterly start date. To compare NASS loss numbers with BIP's (Table I), we combined the quarterly numbers published by NASS to correspond to BIP's division of the seasons into "summer" "winter" and "annual").

We calculated seasonal Total Loss $(G)$ using NASS data and NASS methods using Equation (I):

$$
G=\frac{F}{A}
$$

where the number of colonies lost over the season $(F)$ was the sum of the NASS reported number of colonies lost over the quarter, and the number of colonies at risk of dying $(A)$ was the NASS reported number of colonies at the start of the season. We also calculated seasonal Total Loss $(G)$ using BIP methods and NASS numbers using Equation (I). BIP methods calculates the total number of colonies at risk of dying $(A)$ using Equation (2):

$$
A=S+C-D
$$

where $S$ is the number of colonies at the start of a season, $C$ is the number of colonies added (splits and additions), and $D$ is the number of colonies sold during a period. However, NASS does not report the number of splits or purchases made. Nor does NASS report the loss rate of splits made during a quarter. Therefore, when calculating the total loss rate with BIP-like methods using NASS numbers, the number of colonies lost $(F)$ was calculated using Equation (3):

$$
F=A-\left(S_{2}\right)
$$

where $A$ is the number of colonies at the start of the period, and $S_{2}$ is the number of colonies at the start of the next period. In the case where NASS has not yet reported the $S_{2}$ (e.g., after 4th quarter), we estimated $\mathrm{S}_{2}$ by summing the number of colonies remaining after the period (e.g., colonies at start of period - lost colonies during the period + added colonies during the period) and the total number of additions made during the period. In other words, we assumed that none of the additions died during the fourth quarter (e.g., JanuaryMarch).

For annual loss estimates, using NASS numbers and BIP-like methods, the additions from the first three quarters were added to the starting colonies. In each case, as per NASS standards, splits made during the most recent quarter (most recent splits) are not considered in the pool of colonies at risk (Table I).

\section{Results}

\section{Average and total losses}

There were 7535 beekeepers who responded to this survey. We identified and invalidated 399 duplicates and $34 \mathrm{I}$ non-US respondents, leaving 6795 valid 
Table I. Summary of NASS-published data including number of colonies at the start of each season (Colonies Start), colonies added (Added), number of colonies at risk (Total colonies at Risk $=$ Colonies Start + Added), colonies lost (Lost), and Total Loss (\%). Total loss is calculated using both NASS and BIP-like methodologies for comparison of results.

NASS numbers, NASS periods, NASS reported losses (USDA-NASS, 2016)

\begin{tabular}{lcccc}
\hline Season & Colonies at & & \multicolumn{2}{c}{ Total loss (\%) (=lost/colonies } \\
start)
\end{tabular}

NASS numbers, BIP seasons, NASS-modified method for loss calculation

\begin{tabular}{lccccc}
\hline Season & $\begin{array}{c}\text { Colonies } \\
\text { at start }\end{array}$ & (Added) & $\begin{array}{c}\text { (Total colonies at } \\
\text { risk) }\end{array}$ & $\begin{array}{c}\text { Lost } \\
\text { Summer }\end{array}$ & $\begin{array}{c}\text { Total loss NASS method (\%) } \\
\text { (=lost/colonies start) }\end{array}$ \\
\hline Winter & $2,849,500$ & $(661,860)$ & $(3,511,360)$ & 809,960 & 28.42 \\
& $2,874,760$ & $(172,990)$ & $(2,991,910)$ & 841,180 & 29.26 \\
Annual & $2,849,500$ & $(376,150)$ & $(3,801,500)$ & $1,651,140$ & 57.94 \\
& & $(171,860)$ & & \\
& $(117,990)$ & & & \\
& & $(376,160)$ & & & \\
\hline
\end{tabular}

NASS numbers, BIP seasons, BIP - like method for loss calculation

\begin{tabular}{|c|c|c|c|c|c|c|}
\hline Season & $\begin{array}{l}\text { Colonies } \\
\text { at start }\end{array}$ & Added & $\begin{array}{c}\text { Total } \\
\text { colonies at } \\
\text { end of season }\end{array}$ & $\begin{array}{c}\text { Total colonies } \\
\text { at risk }\end{array}$ & Lost & $\begin{array}{l}\text { Total loss BIP method (\%) } \\
\text { (=lost/total colonies at risk) }\end{array}$ \\
\hline Summer & $2,849,500$ & 834,850 & $2,874,760^{\#}$ & $3,684,350$ & 809,590 & 21.97 \\
\hline Winter & $2,874,760$ & 493,310 & $2,541,950^{\#}$ & $3,368,070$ & 826,120 & 24.53 \\
\hline Annual & $2,849,500$ & $1,328,160$ & $2,541,950$ & $4,177,660$ & $1,635,710$ & 39.15 \\
\hline
\end{tabular}

Notes: Values in parentheses are not used for calculations in those rows.

\#Estimated.

Table 2. A summary of the three colony loss periods (summer, winter, and annual) of the self-reported colony loss data from I April 2015 to I April 2016, with the total number of respondents, the total number of colonies on each date, the total number of colonies increases $(+)$ and decreases $(-)$, and the total loss and average loss for each period $(\%)[95 \% \mathrm{Cl}]$.

\begin{tabular}{lcccccccc}
\hline \multicolumn{7}{c}{ Total colonies alive on: } \\
\cline { 2 - 6 } Season & $n$ & I April & $\begin{array}{c}\text { Net interim } \\
\text { change }\end{array}$ & $\begin{array}{l}\text { I October } \\
2015\end{array}$ & $\begin{array}{c}\text { Net interim } \\
\text { change }\end{array}$ & $\begin{array}{c}\text { I April } \\
2016\end{array}$ & Total loss (\%) & Average loss (\%) \\
\hline Summer & 4875 & 399,055 & $(+) \mid 38,787$ & 411,167 & - & - & $23.6[23.0-24.1 \%]$ & $16.5[15.8-17.2 \%]$ \\
Winter & 5725 & - & - & 427,652 & $(+) 112,222$ & 394,768 & $26.9[26.4-27.4 \%]$ & $37.7[36.8-38.7 \%]$ \\
Annual & 4624 & 373,710 & $(+) \mid 37,603$ & 511,313 & $(+) 98,544$ & 362,954 & $40.5[39.9-41.1 \%]$. & $44.2[43.2-45.2 \%]$ \\
\hline
\end{tabular}

Notes: Sample size $(n)$ is the number of beekeepers providing valid responses. Net interim changes include the numbers of increases $(+)$ by splits or purchases and decreases $(-)$ through selling or giving away during a time period.

responses to comprise our analytical data-set. After invalidating illogical and insufficient responses, we were left with 5725 valid winter responses, 4875 summer responses and 4624 annual responses. These respondents managed a total of 427,652 colonies on I October 2015. Based on USDA-NASS (2016) estimates, this survey represents $16.1 \%$ of all managed honey producing colonies in the US in the summer of 2016. Of the 5725 valid winter loss respondents, 5499 were back- yard beekeepers, 137 were sideline beekeepers, and 89 were commercial beekeepers. On I October 2015, the respondent backyard, sideline, and commercial beekeepers managed 33,254 , 15,705, and 378,693 colonies, respectively.

Total colony loss in 2015-2016 was $23.6 \%$ [95\% Cl 23.0-24.1\%] in summer, $26.9 \%[95 \% \mathrm{Cl} 26.4-27.4 \%]$ in winter, and $40.9 \%$ [95\% Cl 39.9-4I.1\%] annually. Average loss per beekeeper was $16.5 \%$ [95\% Cl 15.8-17.2\%] 
Total Winter Loss by State - Loss Survey 2015-2016

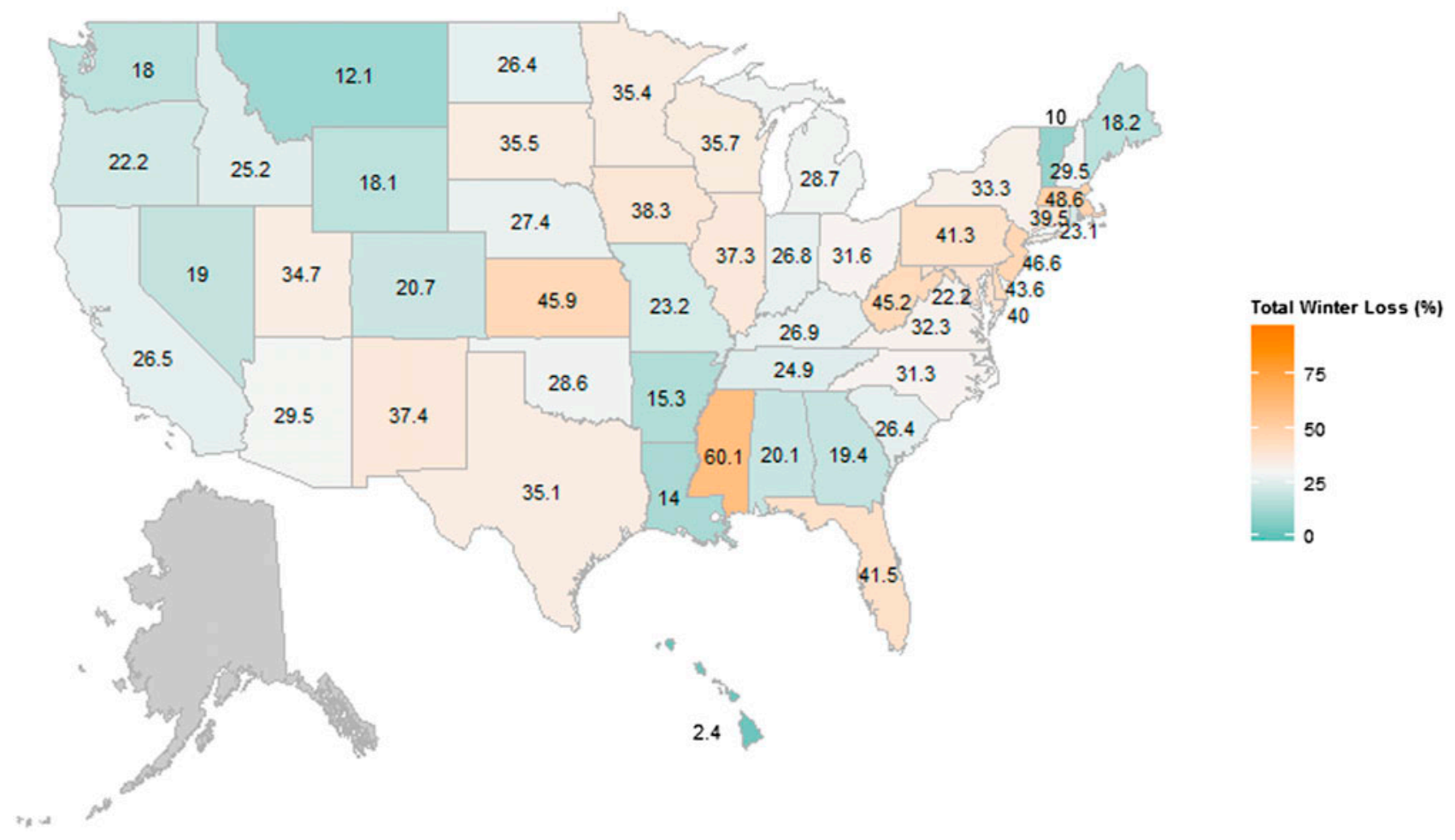

Figure I. Total colony winter losses (\%) reported for each state in the USA.

Average Winter Loss by State - Loss Survey 2015-2016

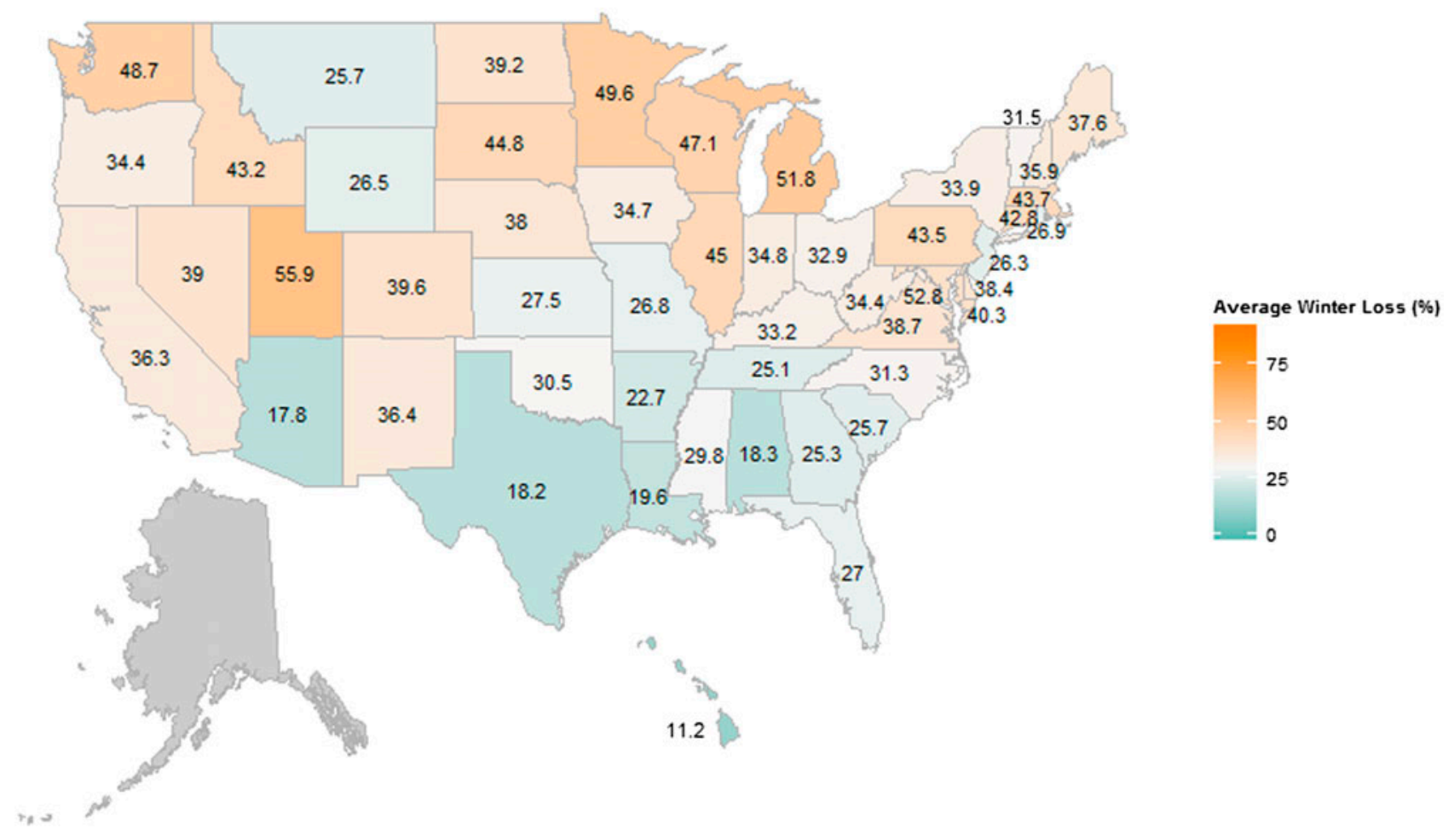

Figure 2. Average colony winter losses (\%) reported for each state in the USA. 
in summer, $37.7 \%$ [95\% Cl 36.8-38.7\%] in winter, and $44.2 \%$ [95\% Cl 43.2-45.2\%] annually (Table 2). Across all operation types, a total of $32.3 \%$ of responding beekeepers reported no winter loss, $99.5 \%$ of which were backyard beekeepers who managed an average of 3 \pm 0.1 colonies.

\section{State losses}

The number of respondents varied between states across all seasons. Puerto Rico had only one valid respondent for the winter loss season, while Pennsylvania had 777. State total losses also varied, from 5.3 to $55.2 \%$ in summer, 2.4 to $60.1 \%$ in winter, and 24.5 to 71.3\% annually (Figure I, Online Supplementary Material Figures $\mathrm{SIa}, \mathrm{SIb}$ ). State average losses ranged from 8.2 to $29.5 \%, 11.2$ to $55.9 \%$, and 18.8 to $60.9 \%$ in summer, winter, and annually, respectively (Figure 2, Online Supplementary Material Figures S2a, S2b).

\section{Losses by operation type}

Each operation type had different numbers of respondents. Because the majority of beekeeping operations in the US are small, backyard beekeepers predominate the survey respondents, representing 96.1\% $(n=5499)$ of winter respondents, 95.7\% $(n=4670)$ of summer and $95.7 \%(n=4426)$ of annual respondents. There were II6 valid sideline beekeepers in summer, 173 in winter, and 114 in the annual portion. There were 89 valid commercial beekeepers in summer 84 in the winter and annual season.

In summer, sideline beekeepers lost on average the fewest number of colonies $(15.1 \% \quad[95 \%$ Cl $11.7-$ 18.5\%]), followed by backyard beekeepers (16.5\% [95\% Cl 15.6-17.2\%] $p<0.005]$. Commercial beekeepers reported the highest rate of loss $(21.1 \%$ [95\% Cl 17.3$24.9 \%$ ]) compared to the other two operation types [vs. backyard: $p<0.000$ I, vs. sideline: $p<0.005$ ]. Summer loss was the only period for which all operation types differed significantly $\left[\chi^{2}=45.39, p<0.0001\right]$. Average losses were the same for all beekeeping groups over the winter $\left[\chi^{2}=1.91, p=0.3849\right]$ and annually $\left[\chi^{2}=3.05, p=0.2174\right]$. Average losses were 38.2\% [95\% $\mathrm{Cl} 37.2-39.1 \%]$ in winter and $44.5 \%$ [95\% Cl 43.445.5\%] annually for backyard beekeepers, 28.7 [95\% Cl $24.6-32.8 \%]$ in winter and $37.6 \%$ [95\% Cl 32.9-42.4\%] annually for sideliners, and $26.3 \%$ [95\% Cl 22.2-30.3\%] in winter and $38.8 \%$ [95\% Cl 34.3-43.2\%] annually for commercial beekeepers (Table 3, Figure 3).

Migratory operations were composed primarily of commercial beekeepers $(83.7 \%, n=72)$. Commercial operations also composed most of the population of respondents who reported using their colonies for almond pollination $(81.4 \%, n=70)$. Beekeepers who reported moving across state lines were categorized as migratory, and experienced average winter loss $(28.4 \%$ [95\% Cl 24.7-32.5\%] that trended lower than stationary beekeepers $(38.0 \%[95 \% \mathrm{Cl} 37.0-39.0 \%])\left[\chi^{2}=3.242\right.$, $p=0.072]$. Beekeepers pollinating almonds lost the same number of colonies (28.1\% [95\% Cl 23.7-32.6\%]) on average as those who reported as not pollinating almonds $(27.5 \% \quad[95 \% \mathrm{Cl} \quad 23.5-3 \mathrm{I} .5 \%]) \quad\left[\chi^{2}=0.02 \mathrm{I}\right.$, $p=0.8853]$.

\section{Acceptable loss}

On average, survey respondents indicated that a loss rate of $19.0 \% \quad[95 \% \mathrm{Cl} 18.5-19.4 \%](n=5,726)$ was acceptable. Commercial beekeepers reported that a $16.5 \%$ [95\% Cl 14.0-19.I] loss rate was acceptable, where sideline and backyard beekeepers reported that $17.4 \%[95 \% \mathrm{Cl}$ |5.|-19.8\%] and 19.0\% [95\% Cl 18.619.5\%] loss rates were acceptable respectively. Using the average reported acceptable loss of $19.0 \%, 59.0 \%$ $(n=3378)$ of beekeepers observed higher losses than they deemed acceptable. These beekeepers had an average loss of $62.2 \%$ [95\% Cl 61.3-63.2\%], which was much higher than beekeepers who lost fewer colonies than the average acceptable loss rate $(2.5 \%[95 \% \mathrm{Cl} 2.3-$ 2.7\%]) $\left[\chi^{2}=4324.2, p<0.000 I\right]$.

Fifty-four percent of responding beekeepers had higher colony loss rates than their own standard of acceptable loss rates. These beekeepers experienced a

Table 3. Self-reported 2015-2016 US colony loss by operation type (total and average loss (\%) [95\% Cl]), showing the number of respondents $(n)$, the total number of colonies at the start of the respective period (\# Colonies (start)) for each of the operation type categories: backyard beekeepers ( $\mathrm{I}-50$ colonies), sideline beekeepers (5I-500 colonies) and commercial beekeepers ( $>500$ colonies). The proportion of colonies owned by different operation types in a given season (\% Colonies (start)) is also reported.

\begin{tabular}{llrcccc}
\hline Season & Operation type & $n$ & \# Colonies (start) & \% Colonies (start) & Total loss (\%) & Average loss (\%) \\
\hline \multirow{2}{*}{ Summer } & Backyard & 4670 & 21,679 & 5.4 & $17.7[17.1-18.4 \%]$ & $16.4[15.7-12.2 \%]$ \\
& Sideline & 116 & 11,275 & 2.8 & $25.5[20.8-30.7 \%]$ & $15.1[11.7-18.5 \%]$ \\
& Commercial & 89 & 366,101 & 91.7 & $23.9[20.3-27.7 \%]$ & $21.1[17.3-24.9 \%]$ \\
& Backyard & 5499 & 33,254 & 7.8 & $34.3[33.5-35.2 \%]$ & $38.2[37.2-39.1 \%]$ \\
Winter & Sideline & 137 & 15,705 & 3.7 & $28.4[25.0-32.5 \%]$ & $28.7[24.6-32.8 \%]$ \\
& Commercial & 89 & 378,693 & 88.6 & $26.3[22.8-30.0 \%]$ & $26.3[22.2-30.3 \%]$ \\
& Backyard & 4426 & 20,530 & 5.5 & $43.5[42.6-44.4 \%]$ & $44.5[43.4-45.5 \%]$ \\
Annual & Sideline & 114 & 9771 & 2.6 & $41.6[36.5-46.8 \%]$ & $37.6[32.9-42.4 \%]$ \\
& Commercial & 84 & 343,409 & 91.9 & $40.3[36.0-44.6 \%]$ & $38.8[34.3-43.2 \%]$ \\
\hline
\end{tabular}




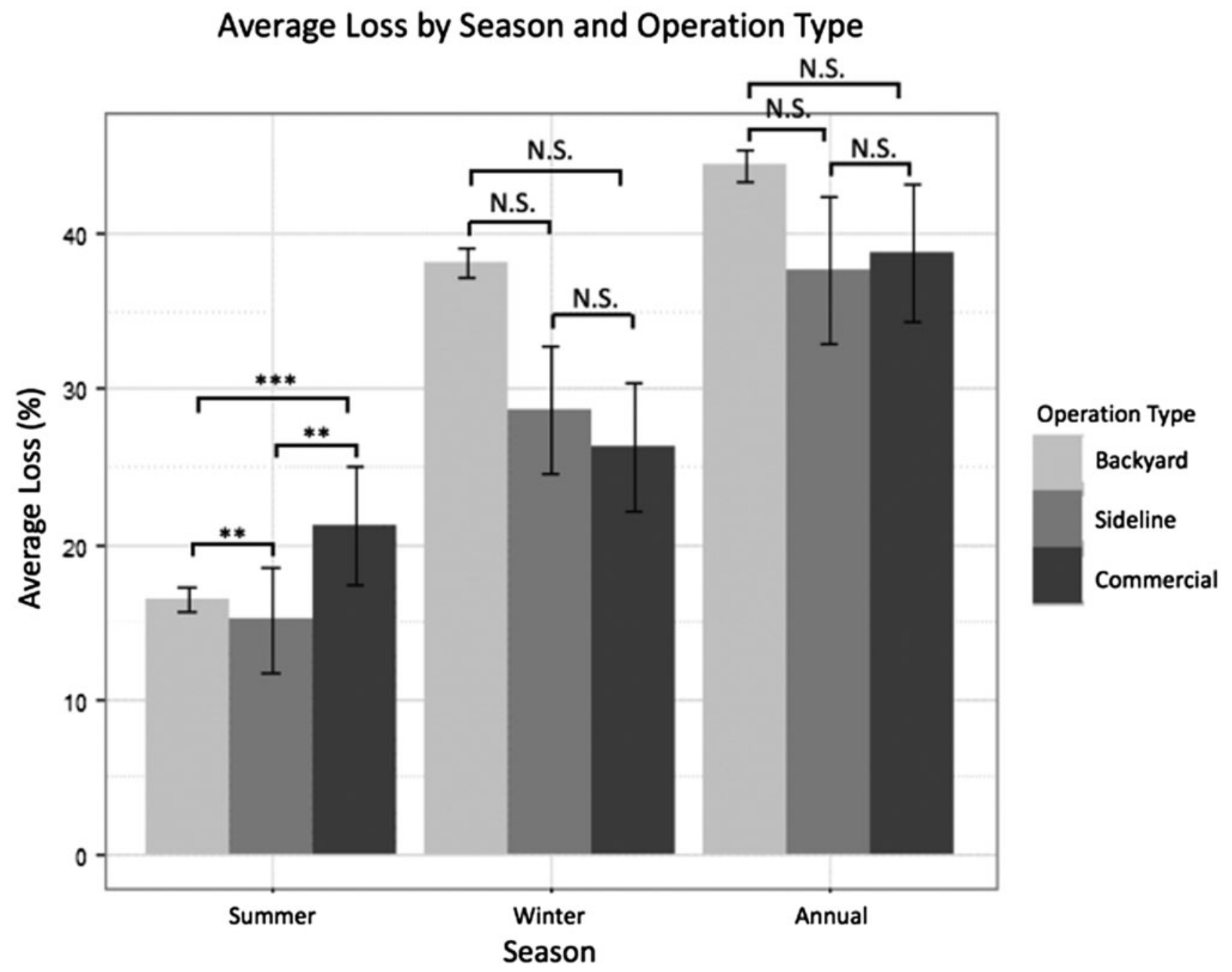

Figure 3. A comparison of the average (\%) summer (I April 2015 to I October 20I5), winter (I October 2015 to I April 20I6), and annual (I April 2015 to I April 2016) colony losses (with 95\% Cl) of three beekeeping operation types (backyard, sideline, and commercial).

Notes: Bars represent $95 \%$ Cl. ${ }^{* *} p<0.01$, ${ }^{* *} p<0.00$ I, N.S.: not significant.

Table 4. Causes of death and association with each commercial type and average loss.

\begin{tabular}{lccccc}
\hline Cause of death & $n$ (total) & $n$ (backyard) (\%) & $n$ (sideline) (\%) & $n$ (commercial) $(\%)$ & Average loss \% [95\% Cl] \\
\hline Queen failure & 933 & $823(88.2 \%)$ & $60(6.4 \%)$ & $50(5.4 \%)$ & $47.3[45.3-49.2]$ \\
Starvation & 766 & $709(92.6 \%)$ & $44(5.7 \%)$ & $13(1.7 \%)$ & $53.4[51.2-55.5]$ \\
Varroa & 1181 & $1042(88.3 \%)$ & $82(6.9 \%)$ & $57(4.8 \%)$ & $55.9[54.2-57.7]$ \\
Nosema & 142 & $116(81.7 \%)$ & $14(9.9 \%)$ & $12(8.4 \%)$ & $52.4[47.5-57.2]$ \\
Small hive beetle (SHB) & 162 & $150(92.6 \%)$ & $6(3.7 \%)$ & $6(3.7 \%)$ & $58.8[54.1-63.5]$ \\
Poor winter & 603 & $583(96.7 \%)$ & $15(2.5 \%)$ & $5(0.8)$ & $65.7[63.3-68.1]$ \\
Pesticides & 274 & $232(84.7 \%)$ & $17(6.2 \%)$ & $25(9.1 \%)$ & $66.1[62.5-69.6]$ \\
Weak in fall & 1210 & $1133(93.6 \%)$ & $55(4.6 \%)$ & $22(1.8 \%)$ & $52.1[50.4-53.8]$ \\
CCD & 401 & $355(88.5 \%)$ & $21(5.3 \%)$ & $25(6.2 \%)$ & $64.0[61.0-66.9]$ \\
Disaster & 103 & $88(85.4 \%)$ & $10(9.7 \%)$ & $5(4.9 \%)$ & $56.0[50.1-61.9]$ \\
Don't know & 952 & $920(96.6 \%)$ & $16(1.7 \%)$ & $16(1.7 \%)$ & $65.2[63.3-67.1]$ \\
Other pests & 104 & $102(98.1 \%)$ & $2(1.9 \%)$ & 0 & $62.1[56.0-68.1]$ \\
Mismanagement & 21 & $20(95.2 \%)$ & $1(4.8 \%)$ & 0 & $54.5[41.7-67.3]$ \\
Other disease/virus & 31 & $24(77.4 \%)$ & $4(12.9 \%)$ & $3(9.7 \%)$ & $51.8[39.8-63.8]$ \\
Other & 183 & $171(93.5 \%)$ & $9(4.9 \%)$ & $3(1.6 \%)$ & $54.5[50.0-59.1]$ \\
\hline
\end{tabular}




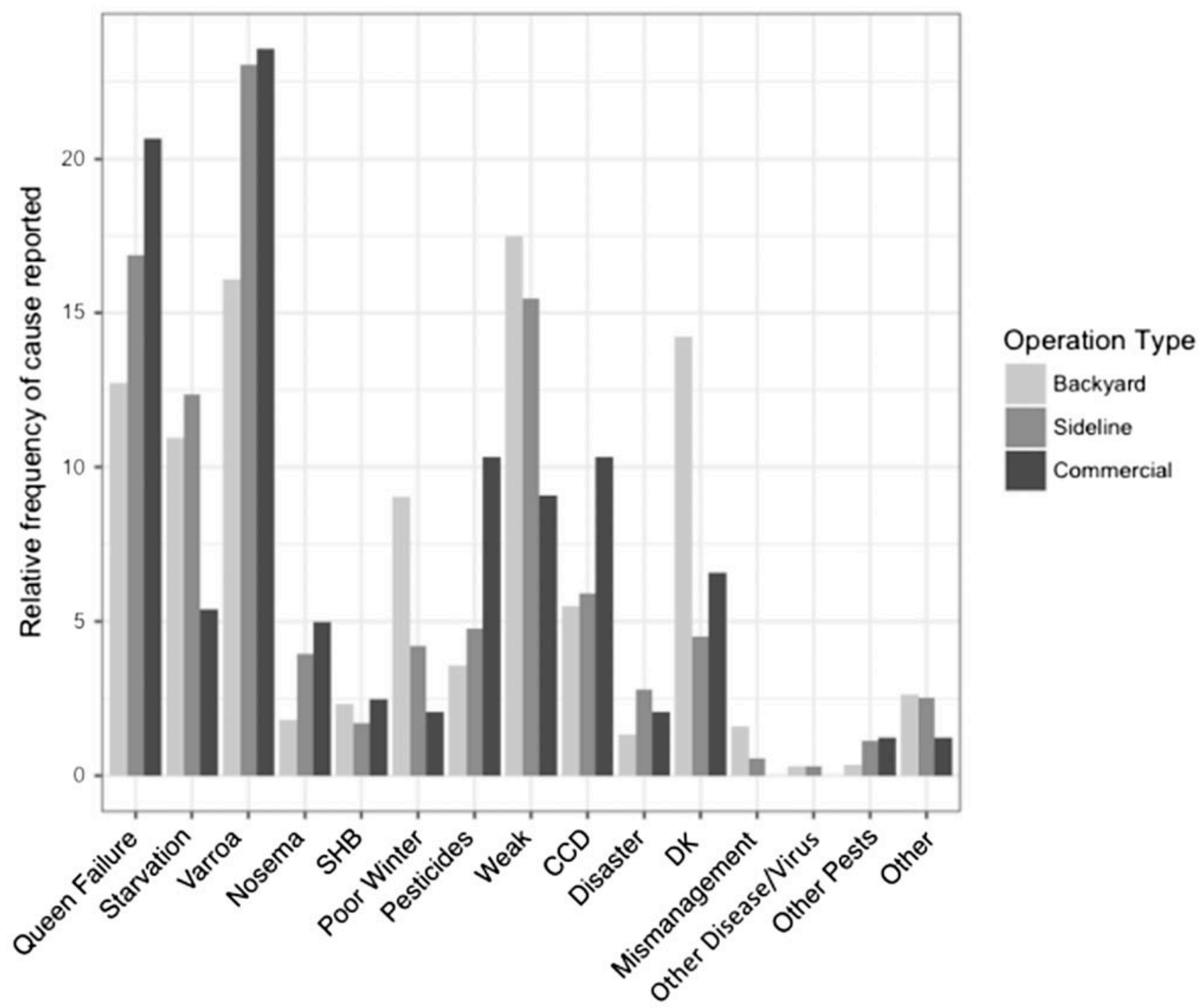

Self Reported Cause of Death

Figure 4. Relative ratio of respondents reporting each cause of loss by operation type.

Notes: SHB: small hive beetle, Weak: weak in the fall, CCD: Colony Collapse Disorder, DK: Don't know.

$62.0 \%$ average loss [95\% $\mathrm{Cl} 61.0-63.0 \%]$ compared to a $7.1 \%$ average loss $[95 \% \mathrm{Cl} 6.5-7.8 \%]$ for those who experienced loss they considered acceptable $\left[\chi^{2}=3,583\right.$, $p<0.0001]$.

\section{Self-reported causes of loss}

Of the 5725 valid winter loss respondents, 3369 (3459 backyard, I3I sideline, 79 commercial) lost at least one colony and reported at least one cause of loss. "Weak in the fall" $(n=|2| 0)$, "Varroa" $(n=|| 8 \mid)$, "Don't know" ( $n=952)$, and "Queen failure" $(n=933)$ were the most commonly selected causes of loss across all operation types (Table 4). Self-reported causes of death differed between operation types. Backyard and sideline beekeepers were more likely to report "Weak in the fall" (reported by 36 and $44 \%$ of backyard and sideline respondents, respectively) and "Varroa" (33, 62\% respectively), while commercial usually reported "Queen failure" (70\%) and "Varroa" (84\%). Backyard beekeepers, often the least experienced group (www.beein formed.org, 2015), were also very likely to report "Don't know" (30\%) (Figure 4).

Average losses differed between those who reported different self-diagnosed causes of loss. Beekeepers who reported "Don't know" as a cause of loss, lost more colonies on average $(65.2 \%$ [95\% Cl 63.3$67.1 \%])$ than those who did not $(52.8 \%$ [95\% Cl 63.667.1\%]) $\left[\chi^{2}=113.2, p<0.05\right]$. Average loss for "Weak in fall" reporters was $52.1 \%$ [95\% Cl 50.4-53.8\%], which is lower than those who did not report "Weak in fall" $\left(58.0 \%\right.$ [95\% Cl 50.4-53.9\%]) $\quad\left[\chi^{2}=28.885, p<0.05\right]$. 


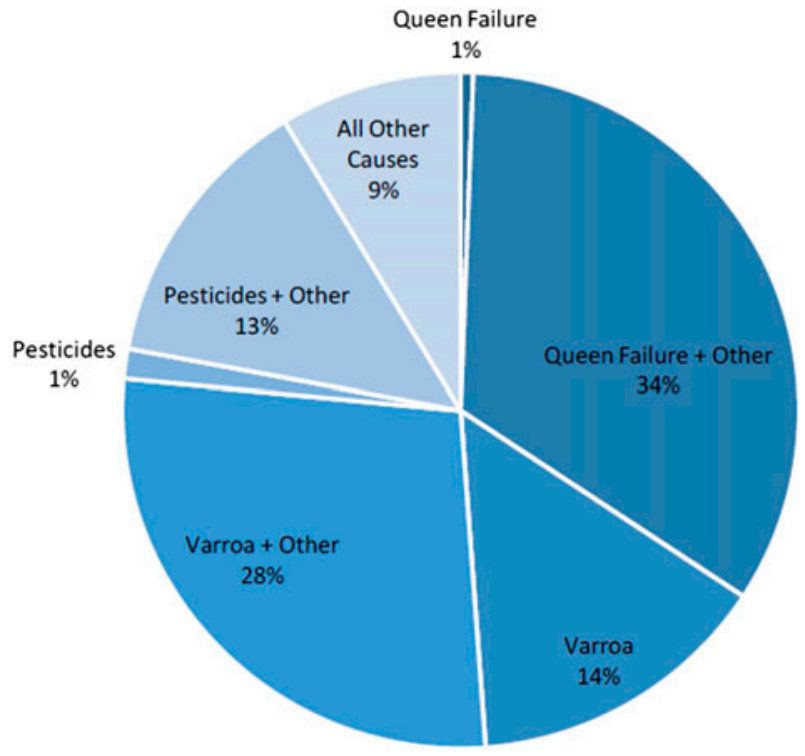

Figure 5. Estimated (see methods) number of colonies lost $(n=132,463)$ due to each commonly self-reported colony health risk factors.

Those who reported "Queen failure" as a cause lost $47.3 \%$ [ $95 \% \mathrm{Cl} 45.3-49.3]$ of colonies on average, which was lower than those who did not report "Queen failure" $\quad(59.0 \% \quad[95 \%$ Cl $57.8-60.2 \%]) \quad\left[\chi^{2}=102.88\right.$, $p<0.05]$. Average loss by those who reported "Varroa" as a cause was $55.9 \%$ [95\% Cl 54.2-57.7\%], and was about the same as those who did not list "Varroa" as a main contributor to their losses $(56.1 \%$ [95\% Cl 54.8 57.3\%]) $\left[\chi^{2}=0.006, p>0.05\right]$.

Beekeepers who reported one or more of the three most commonly reported risk factors associated with colony mortality ("Queen failure," "Varroa," and "Pesticides") experienced a combined loss of 132,463 colonies (Figure 5). These calculations suggest that beekeepers who reported Queen Failure, Varroa, and/or Pesticides lost $91.3 \%$ of total number of colonies lost over the winter $(n=145,106)$.

One survey question asked specifically if the beekeeper lost colonies with the symptom "no dead bees in the hive or apiary," a known symptom of CCD. Of the 3675 valid responses to this question, I619 (1474 backyard, 77 sideline, 68 commercial) beekeepers reported that this symptom was a prominent cause of colony death in their operation. The average loss for those that reported the symptom was $58.8 \%[95 \% \mathrm{Cl}$ $57.3-60.3 \%]$, which is significantly higher than those who did not report it who, on average, lost $53.8 \%$ of colonies [95\% Cl 52.5-55.2\%]) $\left[\chi^{2}=23.35, p<0.0001\right]$.

\section{Comparison to USDA-NASS Survey}

To explore potential differences between the BIP and NASS survey results, we performed four sets of calculations using either numbers collected by BIP or numbers collected by NASS (as described in Methods; Table Ic) (Table 5). Total loss numbers (\%) were calculated using the BIP numbers using BIP loss calculation methodology, NASS numbers using NASS methods and BIP seasons, NASS numbers and BIP loss calculation methods, and BIP numbers using NASS-modified calculation methodology.

As BIP data are collected for every 6-month period, these results do not compare BIP results with NASS published results directly. Furthermore, because NASS divides losses into quarters, it is not possible to calculate the total annual loss using BIP numbers and NASS calculation methodology.

\section{Discussion}

This is the tenth consecutive survey to report winter colony losses, and the fifth to report summer and annual losses. Total winter loss of $26.9 \%$ this year is slightly higher than the $25 \%$ total winter loss reported last year (Seitz et al., 2016) and the 10-year total winter loss average of $24.6 \%$. This year's average winter loss of $44.2 \%$ is consistent with the two highest years of average winter loss in 2012-2013 and 2013-2014 (Lee et al., 20I5; Steinhauer et al., 20l4). Average winter loss, and summer losses that rivaled that of winter losses, emphasize the need for surveys that encompass the entire year if we wish to understand bee health.

Beekeepers reporting no winter colony losses were primarily backyard beekeepers ( $n=1838,99.5 \%)$. These backyard beekeepers had an average operation size of $3.7( \pm 0.1)$ colonies. Furthermore, 17.0\% of backyard beekeepers reported $100 \%$ loss, while only one sideline and zero commercial beekeepers reported 100\% loss. Smaller operations are more likely to retain or lose all of their colonies because they have a smaller margin for error. There were commercial $(n=5)$ and sideline $(n=5)$ beekeepers who reported no loss. This may be a result of the subjective nature of this survey, as beekeepers may approximate or misremember data. Some beekeepers reporting no winter loss did experience a summer loss, indicating they may split heavily in fall and assume they compensated for any potential winter loss.

It is useful to compare colony losses in the USA to those experienced by beekeepers in other countries.

Table 5. Summary of Total colony losses (\%) as calculated by BIP and NASS for each time period.

\begin{tabular}{llcccc}
\hline Total loss estimates (\%) & $\begin{array}{l}\text { BIP numbers } \\
\text { BIP method }\end{array}$ & $\begin{array}{c}\text { NASS numbers } \\
\text { NASS method }\end{array}$ & $\begin{array}{l}\text { NASS numbers } \\
\text { BIP method }\end{array}$ & $\begin{array}{c}\text { BIP Numbers } \\
\text { NASS Method }\end{array}$ \\
\hline Summer & April 2015-September 2015 & 23.55 & 23.07 & 21.97 & 22.65 \\
Winter & October 2015-April 2016 & 26.88 & 28.12 & 24.53 & 23.93 \\
Annual & April 2015-April 2016 & 40.49 & 43.43 & 39.15 & - \\
\hline
\end{tabular}


These comparisons put the severity of US colony mortality rates into context on a global scale and help to identify broader trends. US beekeepers experienced higher winter loss than 27 of the 29 countries included in the 2015-2016 COLOSS survey, surpassed only by Ireland (29.5\%) and Northern Ireland (28.2\%) (Brodschneider et al., 2016). However, these comparisons are very tenuous, because the European survey allows beekeepers to self-define "winter," meaning that some beekeepers in southern countries could report losses over a two week period and northern beekeepers report losses over a period of two or more months. Winter losses estimated in China (10.1\%, 2010-2013; Liu et al., 2016) and Uruguay (20.2\%, 2013-2014; Antúnez, Invernizzi, Mendoza, vanEngelsdorp, \& Zunino, 2017) over past years were also consistently lower than in the USA. Estimates conducted in South Africa $(29.6 \% 2009$ 2010, 46.2\% 2010-20II; Pirk, Human, Crewe, \& vanEngelsdorp, 2014) however, were more similar to losses experienced in the USA. Direct comparisons between datasets should be made with caution as methodologies, sample sizes, and operation types differ between these surveys and the countries represented.

Differences in state losses are explained, at least in part, by differences in climate. Stationary beekeepers who keep colonies in northern states are expected to have higher loss rates as overwintering colonies are more vulnerable to starvation (Brodschneider \& Crailsheim, 2010) and parasite pressures (Desai \& Currie, 2016) due to harsher overwintering conditions such as lack of forage availability, reduced colony size, and cold temperatures. Other, more variable climatic conditions probably played a role in elevated losses. For instance recent drought experienced in some western states (Diffenbaugh, Swain, \& Touma, 2015; Wise, 2016) probably affected winter colony mortality. A warm, dry climate has a pronounced effect on vegetation, which in turn affects honey bee foraging and colony health (Switanek, Crailsheim, Truhetz, \& Brodschneider, 2017).

Typically, commercial beekeepers have lower loss rates than do backyard beekeepers. This year, while numerically true for all seasons, only total and average summer losses were significantly different for the beekeeper groups, with commercial beekeepers losing more colonies in the summer than backyard beekeepers.

Commercial beekeepers manage more colonies and are the most likely to migrate colonies and participate in California almond pollination. These activities expose colonies to stresses such as transport, pesticide exposure, and nutritional monocultures (Huang, 2012; Pettis et al., 2013; Simone-Finstrom et al., 2016). In the ten years of this survey including this year, operations categorized as migratory or participating in almond pollination had the same or lower losses compared with those who did not migrate or pollinate almonds (Lee et al., 2015; Seitz et al., 2016; Spleen et al., 2013; Steinhauer et al., 20I4; vanEngelsdorp et al., 2007, 2008, 2010,
20II, 20I2). Migratory beekeepers and those pollinating almonds are typically commercial, and these beekeepers generally tend to experience lower loss.

Almost $60 \%$ of beekeepers reported losing more than the average loss deemed acceptable $(19.0 \%)$ by beekeepers in 2016. In the past, average acceptable loss has ranged from $13.2 \%$ to a high of $19.0 \%$ annually (Lee et al., 2015; Seitz et al., 2016; Spleen et al., 2013; Steinhauer et al., 2014; vanEngelsdorp et al., 2007, 2008, 2010, 20II, 2012). Prior to 2013-2014 when average acceptable loss was also 19.0\%, acceptable loss rates were never higher than $14.6 \%$. The upward trend of reported acceptable loss suggests that beekeepers are expecting higher losses than in the past.

Frequent media reports of high colony losses could have an effect on beekeeper outlook, influencing their perception of their loss rates. Adaptation of the beekeeping industry to continuous years of higher than acceptable loss rates may have also increased beekeeper expectation of loss. As annual colony loss rates remain high in the USA, beekeeper attitude and acceptability of colony loss may also remain high.

The self-reported cause of loss survey question provides a unique opportunity to track trends in what beekeepers think the underlying colony health issues are in their operations. What beekeepers report tends to differ between operation types. Commercial beekeepers tend to report direct and known risk factors that correlate to colony losses such as "Varroa" (Genersch et al., 2010; Giacobino et al., 2015) and "Queen failure" (Brodschneider et al., 2016; vanEngelsdorp et al., 2013). Backyard beekeepers, on average, are more likely to assign factors that are more easily mitigated by good management, such as "Weak in the fall" or "Starvation," both of which can be mediated by timely and proper feeding strategies. For those who reported losing colonies with the CCD symptom of no dead bees, it is important to note that this is only one symptom of CCD, and does not mean that CCD was the actual cause of death.

This year, for the first time, backyard beekeepers reported "Varroa" as one of the leading causes of colony loss. This may indicate that outreach efforts aimed at promoting varroa control are penetrating the backyard beekeeper community. Ideally, increased awareness of varroa issues will increase the adoption of year-round varroa monitoring and management plans.

The "National strategy to promote the health of honey bees and other pollinators" released by the White House (Vilsack \& McCarthy, 2015) called for national honey bee winter loss of under $15 \%$ within ten years. Using the assumptions outlined above: Self-reported Cause of Loss, the removal of the three most commonly identified direct risk factors ("Queen failure," "Varroa," and "Pesticides") reduces this year's total winter loss of $26.9-2.4 \%$. This emphasizes the impact of these risk factors on national winter colony losses, as well as the need for further research into quantifying 
the impact of various risk factors associated with colony mortality and development of strategies to mitigate these risks.

While both the BIP and NASS survey share the goal of estimating loss rates in managed honey bee colonies, both surveys differ somewhat in their approach and reporting. NASS's survey differed from ours in questions asked, delivery of surveys, data presentation, and methodology of loss calculations. NASS divides, collects and reports loss numbers and rates in quarterly time periods only (I April-30 June, I July-30 September, I October-3 I December, I January-3 I March) as opposed to BIP's reporting of summer, winter, and annual loss numbers and rates. NASS also calculates loss by directly asking the beekeeper how many colonies died in each quarter, while BIP indirectly calculates the number of colonies lost by calculating the difference in expected and actual colonies reported alive at the end of a specific period. This means that NASS's approach would not include the death of colonies that resulted from splits made within a survey period, while BIP methods would account for such colonies. Despite this difference, NASS loss numbers, once transformed to BIP seasons (e.g., summer and winter), are strikingly similar (Table 5). In fact, summer losses reported by NASS fall within the $95 \% \mathrm{Cl}$ of BIP summer losses, while winter losses reported by NASS are just above the upper bound of the BIP total winter loss $95 \% \mathrm{Cl}$ (Table 2). The advantage of having two different survey methods conducted on this large scale to generate the same estimates lies in the ability to compare results. Regardless of stark differences in methods, both survey results were comparable. The two surveys serve to validate the assumption that different methods can be used to generate valid, representative estimates of colony loss.

This survey further contributes to the long-term monitoring of trends in honey bee colony losses in the USA. It demonstrates the importance of tracking both winter and summer losses, as summer losses have rivaled winter losses for the last three years. Although losses recorded in this survey are only slightly higher than previous loss averages, these losses still remain higher than those which beekeepers consider acceptable, even as this level of acceptable losses self-reported by beekeepers continues to climb.

Apparent growing awareness of the role of varroa in colony losses, especially among backyard beekeepers, is encouraging, as these losses are probably responsible for the plurality of colony loss in the USA. Continued colony loss surveys and monitoring are essential for documenting both negative and positive changes in the US beekeeping industry.

\section{Supplementary material}

Supplementary material is available for this article at https://doi.org//0.1080/002 I8839.2017.1344496.

\section{Acknowledgements}

We thank all of the respondents for their participation. We thank Ashrafun Nessa for entering paper surveys. Our gratitude goes out to the many beekeeping organizations, industry leaders, and beekeeping clubs that forwarded our email appeal for participation. A special thank you is owed to USDA-APHIS, the Apiary Inspectors of America, Eastern Apiculture Society, the American Honey Producers Association, the American Beekeeping Federation, Brushy Mountain Bee Farm, Bee Culture magazine, Project Apis m. and American Bee Journal for sending out participation requests to their online audiences. This project was funded by a Coordinated Agricultural Project (CAP) grant from US Department of Agriculture-National Institute of Food and Agriculture (USDA-NIFA): the Bee Informed Partnership Inc. and includes in addition to several of the authors, Marla Spivak, Jerry Hayes, Robert Snyder, Ben Sallman, Ellen Topitzhofer, Dan Wyns, John Klepps, Phoebe Koenig, and Jonathan Engelsma. Thank you to the reviewers for their helpful comments.

\section{Disclosure statement}

No potential conflict of interest was reported by the authors.

\section{Funding}

This work was supported by National Institute of Food and Agriculture [grant number 201 I-67007-200 I7].

\section{ORCID}

Kelly Kulhanek (D) http://orcid.org/0000-000I-8920-2327 Nathalie Steinhauer (D) http://orcid.org/0000-0003-2215-5I7X Jeff S Pettis (i) http://orcid.org/0000-0002-4986-6978 James T Wilkes (D) http://orcid.org/0000-0002-4356-9964 Robyn Rose (D) http://orcid.org/0000-0002-2021-5282 Juliana Rangel (D) http://orcid.org/0000-0002-0586-9245

\section{References}

Antúnez, K., Invernizzi, C., Mendoza, Y., vanEngelsdorp, D., \& Zunino, P. (2017). Honey bee colony losses in Uruguay during 2013-2014. Apidologie, 48, 364-370. doi:I0.1007/ s13592-016-0482-2

Berthoud, H., Imdorf, A., Haueter, M., Radloff, S., \& Neumann, P. (20/0). Virus infections and winter losses of honey bee colonies (Apis mellifera). Journal of Apicultural Research, 49, 60-65. doi:I0.3896/IBRA.1.49.1.08

Borneck, R., \& Merle, B. (1989). Trial to evaluate the economic incidence of the pollinating honey bee in the European agriculture. Apiacta.

Brodschneider, R., \& Crailsheim, K. (2010). Nutrition and health in honey bees. Apidologie, 4I, 278-294.

Brodschneider, R., Gray, A., Zee, R.v.d., Adjlane, N., Brusbardis, V., Charrière, J.-D., ... Woehl, S. (2016). Preliminary analysis of loss rates of honey bee colonies during winter 2015/16 from the COLOSS survey. Journal of Apicultural Research, 55, 375-378. doi:10.1080/ 00218839.2016 .1260240

Calderone, N.W. (20I2). Insect pollinated crops, insect pollinators and US agriculture: Trend analysis of aggregate data for the period 1992-2009. PLoS ONE, 7, e37235. doi: 10.137 I/journal.pone. 0037235

Carreck, N.L., \& Williams, I. (1998). The economic value of bees in the UK. Bee World, 79, II5-123. doi:10.1080/ $0005772 X .1998 .11099393$

Cox-Foster, D.L., Conlan, S., Holmes, E.C., Palacios, G., Evans, J.D., Moran, N.A., ... Lipkin, W.I. (2007). A metagenomic 
survey of microbes in honey bee colony collapsedisorder Science, 3/8, 283-287. doi: I 0.1 | 26/science. I |46498

Decourtye, A., Mader, E., \& Desneux, N. (2010). Landscape enhancement of floral resources for honey bees in agroecosystems. Apidologie, 4I, 264-277. doi:10.105I/apido/ 2010024

Desai, S.D., \& Currie, R.W. (2016). Effects of wintering environment and parasite-pathogen interactions on honey bee colony loss in north temperate regions. PLoS ONE, I I(7).

Diffenbaugh, N.S., Swain, D.L., \& Touma, D. (2015). Anthropogenic warming has increased drought risk in California. Proceedings of the National Academy of Sciences, I I 2, 393 I-3936.

Ellis, J.D., Evans, J.D., \& Pettis, J. (2010). Colony losses, managed colony population decline, and Colony Collapse Disorder in the United States. Journal of Apicultural Research, 49, I34-I36. doi:I0.3896/IBRA. I.49.I.30

Gallai, N., Salles, J.-M., Settele, J., \& Vaissière, B.E. (2009). Economic valuation of the vulnerability of world agriculture confronted with pollinator decline. Ecological Economics, 68, 810-821.

Genersch, E., von der Ohe, W., Kaatz, H., Schroeder, A., Otten, C., Berg, S., \& Rosenkranz, P. (20I0). The German bee monitoring project: A long term study to understand periodically high winter losses of honey bee colonies. Apidologie, 4I, 332-352.

Giacobino, A., Molineri, A., Cagnolo, N., Merke, J., Orellano, E., Bertozzi, E., . . . Signorini, M. (2015). Risk factors associated with failures of Varroa treatments in honey bee colonies without broodless period. Apidologie, I-10. doi: | 0.1007/s | 3592-015-0347-0

Huang, Z. (20I2). Pollen nutrition affects honey bee stress resistance. Terrestrial Arthropod Reviews, 5, 175-189. doi: I0.II63/I874983 I2×639568

Lee, K.V., Steinhauer, N., Rennich, K., Wilson, M.E., Tarpy, D.R., Caron, D.M., \& Bee Informed, P. (2015). A national survey of managed honey bee 20I3-20I4 annual colony losses in the USA. Apidologie, 46, 292-305. doi:10.1007/ sI3592-0I5-0356-z

Liu, Z., Chen, C., Niu, Q., Qi, W., Yuan, C., Su, S., \& Shi, W. (2016). Survey results of honey bee (Apis mellifera) colony losses in China (2010-2013). Journal of Apicultural Research, 55, 29-37. doi:10.1080/00218839.2016.1193375

Morse, R.A., \& Calderone, N.W. (2000). The value of honey bees as pollinators of U.S. crops in 2000. Bee Culture, 2-15.

Neumann, P., \& Carreck, N.L. (2010). Honey bee colony losses. Journal of Apicultural Research, 49(I), I-6. doi: I0.3896/IBRA.I .49.I.0I

Pettis, J.S., Lichtenberg, E.M., Andree, M., Stitzinger, J., Rose, R., \& vanEngelsdorp, D. (2013). Crop pollination exposes honey bees to pesticides which alters their susceptibility to the gut pathogen Nosema ceranae. PLOS ONE, 8, I-9. doi: I0.137|/journal.pone.0070182

Pirk, C.W.W., Human, H., Crewe, R.M., \& vanEngelsdorp, D. (20I4). A survey of managed honey bee colony losses in the Republic of South Africa-2009 to 20II. Journal of Apicultural Research, 53, 35-42. doi:I0.3896/IBRA.I.53.I.03

R Development Core Team. (2016). R: A language and environment for statistical computing. Vienna: R Foundation for Statistical Computing. ISBN 3-90005I-07-0 Retrieved from https://www.r-project.org/

Seitz, N., Traynor, K.S., Steinhauer, N., Rennich, K., Wilson, M.E., Ellis, J.D., ... vanEngelsdorp, D. (2016). A national survey of managed honey bee 2014-2015 annual colony losses in the USA. Journal of Apicultural Research, I-12. doi: 10.1080/00218839.2016.1I53294

USDA-NASS. (2016). Honey bee colonies. Washington, DC: Department of Agriculture.

Simone-Finstrom, M., Li-Byarlay, H., Huang, M.H., Strand, M.K., Rueppell, O., \& Tarpy, D.R. (20I6). Migratory management and environmental conditions affect lifespan and oxidative stress in honey bees. Scientific Reports, 6, 810. doi:10.1038/ srep32023

Spleen, A.M., Lengerich, E.J., Rennich, K., Caron, D., Rose, R., Pettis, J.S., ... vanEngelsdorp, D. (20I3). A national survey of managed honey bee 2011-12 winter colony losses in the United States: Results from the bee informed partnership. Journal of Apicultural Research, 52, 44-53. doi:10.3896/ ibra.I.52.2.07

Steinhauer, N.A., Rennich, K., Wilson, M.E., Caron, D.M., Lengerich, E.J., Pettis, J.S., \& vanEngelsdorp, D. (2014). A national survey of managed honey bee 2012 ?2013 annual colony losses in the USA: Results from the bee informed partnership. Journal of Apicultural Research, 53(I), I-I8. doi:10.3896/ibra.I.53.1.01

Switanek, M., Crailsheim, K., Truhetz, H., \& Brodschneider, R. (2017). Modelling seasonal effects of temperature and precipitation on honey bee winter mortality in a temperate climate. Science of the Total Environment, 579, I58I-I587. doi: 10.1016/j.scitotenv.2016.11.178

Traynor, K.S., Pettis, J.S., Tarpy, D.R., Mullin, C.A., Frazier, J.L., Frazier, M., \& vanEngelsdorp, D. (2016). In-hive pesticide exposome: Assessing risks to migratory honey bees from in-hive pesticide contamination in the Eastern United States. Scientific Reports, 6, I. doi:10.1038/srep33207

vanEngelsdorp, D., Caron, D., Hayes, J., Underwood, R., Henson, M., Rennich, K., \& Pettis, J. (20/2). A national survey of managed honey bee 2010-11 winter colony losses in the USA: Results from the bee informed partnership. Journal of Apicultural Research, 5I, II5-124. doi:I0.3896/ibra.I.5I.I.I4

vanEngelsdorp, D., \& Meixner, M.D. (20I0). A historical review of managed honey bee populations in Europe and the United States and the factors that may affect them. Journal of Invertebrate Pathology, 103, S80-S95. doi:I0.1016/j.jip.2009.06.01 I

vanEngelsdorp, D., Hayes Jr., J., Underwood, R.M., \& Pettis, J. (2008). A survey of honey bee colony losses in the U.S., Fall 2007 to Spring 2008. PLoS ONE, 3. doi:10.137I/journal.pone.000407I

vanEngelsdorp, D., Hayes, J., Underwood, R., \& Pettis, J. (2010). A survey of honey bee colony losses in the United States, fall 2008 to spring 2009. Journal of Apicultural Research, 49, 7-I4. doi:I0.3896/IBRA.I.49.1.03

vanEngelsdorp, D., Hayes, J., Underwood, R., \& Pettis, J. (20II). A survey of managed honey bee colony losses in the USA, fall 2009 to winter 2010. Journal of Apicultural Research, 50(I), I-10. doi:I0.3896/ibra.I.50.I.0I

vanEngelsdorp, D., Lengerich, E., Spleen, A., Dainat, B., Cresswell, J., Bayliss, K., ..., Saegerman, C. (20I3). Standard epidemiological methods to understand and improve Apis mellifera health. In V. Dietemann, J.D. Ellis \& P. Neumann (Eds), The COLOSS BEEBOOK: Volume II: Standard methods for Apis mellifera pest and pathogen research. Journal of Apicultural Research, 52(4). doi:I0.3896/IBRA. I.52.4.I5

vanEngelsdorp, D., Underwood, R.M., Caron, D., \& Hayes, J. (2007). An estimate of managed colony losses in the winter of 2006-2007: A report commissioned by the Apiary Inspectors of America. American Bee Journal, 147(599-603).

Vilsack, T., \& McCarthy, G. (20I5). National strategy to promote the health of honey bees and other pollinators. Washington, DC: The White House.

Wise, E.K. (2016). Five centuries of US West Coast drought: Occurrence, spatial distribution, and associated atmospheric circulation patterns. Geophysical Research Letters, 43, 4539-4546.10.1002/2016GL068487

Zhu, W., Schmehl, D.R., Mullin, C.A., \& Frazier, J.L. (20l4). Four common pesticides, their mixtures and a formulation solvent in the hive environment have high oral toxicity to honey bee larvae. PLOS ONE, 9, e77547. doi:10.1371/journal.pone. 0077547 